\title{
Kualitas Hijauan Rumput Gajah (Pennisetum purpureum) Berbeda Tipe
} Pertumbuhan: Review kuantitatif

\author{
Quality of Napier Grass Forage (Pennisetum purpureum) with Different Growth Type: Quantitative Review
}

\section{E H Dumadi, L Abdullah, H A Sukria}

Corresponding email: herudumadi@gmail.com

Departemen Ilmu Nutrisi dan Teknologi Pakan Fakultas Peternakan IPB University, Jl. Agatis Kampus IPB Dramaga, Bogor, Indonesia

Submitted: $30^{\text {th }}$ December 2020 Accepted : $24^{\text {th }}$ March 2021

\section{ABSTRACT}

Study on the data of forage quality was conducted to determine the quality of napier grass forage with different growth and morfological type. In Indonesia, there are two types of napier grass, namely the tall and short type. The data used in this study were of proximate and van soest analysis of tall-type napier grass forage Pennisetum purpureum Schum and short-type napier grass, cultivar Mott dwarf, which were obtained from the Bekasi Feed Quality and Certification Center and data obtained from journals. The results of the study showed that dry matter content of short-type napier grass was higher than those of tall-type napier grass (23\% vs 20\%), while fiber fractions such as crude fiber, NDF and ADF of short-type napier grass were lower than those of tall-type napier grass $32 \%$ vs $29 \%, 70 \%$ vs $65 \%, 43 \%$ vs $39 \%$, respectively. It is therefore relative forage quality (RFQ) of short-type napier grass was higher than those of tall-type napier grass (68 vs 57). It is concluded that related to dry matter and fiber fraction value, the quality of short-type napier grass (cv. Mott) is better than those of tall-type napier grass.

Key words: cultivar Mott, Pennisetum purpureum, relative forage quality (RFQ), shorttype napier grass, tall-type napier grass

\section{ABSTRAK}

Kajian data kualitas hijauan dilakukan untuk mengkaji kualitas hijauan rumput gajah yang berbeda tipe pertumbuhan dan secara morfologi berbeda. Di Indonesia terdapat dua tipe rumput gajah yaitu tipe tinggi dan tipe pendek. Data yang digunakan dalam kajian ini adalah hasil analisis proksimat dan Van Soest dari sampel hijauan rumput gajah tipe tinggi yaitu Pennisetum purpureum dan rumput gajah tipe pendek kultivar Mott dwarf, yang diperoleh dari Laboratorium Pengujian Pakan, buku dan data yang diperoleh dari jurnal. Hasil kajian menunjukan kandungan bahan kering rumput gajah tipe pendek lebih tinggi dibandingkan dengan bahan kering rumput gajah tipe tinggi (23\% vs $20 \%$ ), sedangkan fraksi serat seperti serat kasar, NDF dan ADF pada hijauan rumput gajah tipe pendek lebih rendah dibandingkan fraksi serat hijauan rumput gajah tipe tinggi berturut turut (32\% vs $29 \%, 70 \%$ vs $65 \%, 43 \%$ vs $39 \%$ ) sehingga nilai kualitas hijauan (RFQ) hijauan rumput gajah tipe pendek lebih tinggi dibandingkan dengan nilai RFQ hijauan rumput gajah tipe tinggi (68 vs 57). Kesimpulan dari kajian ini adalah terkait bahan kering dan fraksi serat kualitas hijauan rumput gajah tipe pendek kultivar Mott lebih baik dibandingkan kualitas hijauan rumput gajah tipe tinggi.

Kata kunci: kualitas hijauan relatif (RFQ), kultivar Mott, Pennisetum purpureum, rumput gajah tipe pendek, rumput gajah tipe tinggi 


\section{PENDAHULUAN}

Hijauan pakan merupakan pakan utama ternak ruminansia. Nilai biologis suatu pakan ditentukan oleh kandungan nutrien pada hijauan dan nilai kecernaannya di dalam rumen. Kualitas hijauan pakan sangat beragam tergantung jenis, umur panen, fase pertumbuhan dan manajemen budidaya. Saat ini Indonesia sudah memiliki standar hijauan pakan yang digunakan sebagai acuan dalam memilih hijauan pakan ternak berkualitas yaitu Kepmentan 430/Kpts/KN.200/M/7/2019 tentang Penetapan Persyaratan Teknis Minimal Mutu dan Keamanan Pakan dan/atau Bahan Pakan. Standar kualitas ini dibuat berdasarkan hasil analisis proksimat, Kalsium (Ca), Fosfor (P) dan Van Soest (Van Soest et al. 1991) yang dilakukan beberapa kali dengan berbagai kondisi dan jenis hijauan yang berbeda. Selain parameter tersebut, dalam bisnis praktis kualitas hijauan pakan menjadi lebih rasional dengan menyertakan nilai indeks Relative Forage Quality (RFQ). Indeks RFQ menggambarkan nilai intrinsik bahan yang mempertimbangkan kualitas nutrisinya sehingga pengguna (produsen, penjual, pembeli maupun pemerintah selaku regulator) bisa melakukan transaksi bisnis hijauan pakan secara rasional dan terukur. Selain itu nilai RFQ dapat mewakili nilai keekonomian hijauan pakan yang lebih proporsional, yang dapat memacu sistem perdagangan hijauan yang baik. Ditambahkan oleh Sukria \& Krisnan (2009), bahwa penetapan standar kualitas merupakan langkah penting untuk membangun sistem perdagangan hijauan yang baik, standar kualitas tersebut dapat digunakan dalam penentuan harga. Selain itu, dengan adanya standar, peternak dapat memberikan pakan pada ternaknya secara rasional sesuai dengan standar kualitas yang diberikan. RFQ digunakan sebagai penduga kualitas yang lebih komprehensif karena melibatkan parameter fraksi serat seperti NDF (neutral ditergent fiber) dan ADF (acid ditergent fiber) yang masing-masing secara berturut-turut menjadi penentu asupan bahan kering (dry matter intake) dan kecernahan bahan kering (dry matter digestibility).

Di Indonesia terdapat dua tipe pertumbuhan tanaman rumput gajah yaitu tipe tegakan tinggi dan tipe tegakan rendah atau disebut dwarf. Kedua tipe rumput gajah ini kini banyak dikembangkan oleh masyarakat. Kedua tipe rumput gajah tersebut diduga memiliki perbedaan kualitas yang disebabkan oleh perbedaan morfologinya. Di lapangan menunjukan bahwa kualitas hijauan belum menjadi faktor utama dalam jual beli, tetapi lebih diutamakan kuantitasnya, padahal kualitas hijauan sangat menentukan secara langsung terhadap performa ternak yang dipelihara. Banyak pengguna menilai kualitas hijauan berdasarkan penampilan. Upaya untuk menilai kualitas hijauan dengan cara ini kemungkinan besar akan mengarah pada keputusan pembelian dan pemberian makan yang keliru dan tidak ekonomis. Evaluasi nilai nutrisi hijauan memungkinkan pengguna untuk menilai pakan hijauan yang tersedia secara lebih akurat, mengembangkan ransum yang seimbang, dan menggunakan hijauan dengan lebih hemat biaya dalam program pemberian pakan, serta informasi kualitas akurat dalam pemasarannya. Penentuan kualitas hijauan modern dapat dilakukan dengan cepat dan hemat biaya. Selain itu, ahli nutrisi telah mengembangkan indeks RFQ menjadi alat yang mudah digunakan untuk membandingkan lot hijauan. Dengan pengembangan $R F Q$, pengguna dapat membuat perbandingan antara lot hijauan dari spesies yang sangat berbeda dan menentukan apakah lot tersebut sesuai dengan kelas ternak yang diberi makan. Setelah ditentukan, kegunaan dan nilai ekonomis dari lot hijauan dapat disempurnakan melalui pengembangan ransum dengan menggunakan aspek kualitas hijauan lainnya, seperti TDN (total digestible nutrient), energi bersih dan metabolismenya, PK (protein kasar) dan lainnya. User juga harus menyadari pengaruh manajemen terhadap kualitas hijauan. Faktor kunci, seperti kematangan dari tanaman saat panen dan spesies hijauan, harus menjadi titik fokus (Hancock et al. 2017).

Kualitas hijauan dapat dinyatakan sebagai indeks, seperti indeks Relative Feed Value (RFV) dan RFQ. Indeks ini dapat digunakan untuk menilai potensi hijauan dalam mempengaruhi performa ternak. Semakin besar indeks, semakin baik kualitas hijauan (Romero et al. 2015). Indeks RFV dikembangkan oleh American Forage dan Grassland Council (Rohweder, 1978), dan indeks RFQ dikembangkan oleh Moore dan Undersander (2003). Indeks RFQ adalah usaha perbaikan dari indeks RFV untuk para pembeli dan penjual hijauan, dan hal tersebut lebih baik dalam mencerminkan kinerja yang diharapkan dari ternak yang diberi makan hijauan tersebut. Indeks RFQ telah dikembangkan untuk mengatasi perbedaan ini. Indeks ini mempertimbangkan perbedaan kecernaan fraksi serat dan dapat digunakan untuk memprediksi performa ternak secara lebih akurat dan mencocokkan dengan kebutuhan ternak (Jeranyama \& Garcia, 2004).

Penelitian bertujuan untuk menganalisis data kualitas hijauan rumput gajah tipe pertumbuhan berbeda yaitu tipe tinggi dan tipe pendek dan mendapatkan informasi kualitas terbaik dari kedua tipe rumput gajah tersebut dengan memperhatikan kandungan nutrient termasuk frasi serat dan nilai RFQ.

\section{METODE}

Materi yang digunakan berupa data sekunder dari jurnaljurnal ilmiah, dan laporan hasil pengujian laboratorium uji terkait hijauan makanan ternak di Indonesia. Alat 
Tabel 1 Perbedaan karakteristik morfologi rumput $P$ purpureum dengan $P$ purpureum 'Mott'

\begin{tabular}{lcccc}
\hline \multirow{2}{*}{ Uraian } & \multicolumn{3}{c}{ Jenis rumput } \\
\cline { 2 - 5 } & Nilai & P purpureum & Nilai & P purpureum 'Mott' \\
\cline { 2 - 5 } & $5-13$ & Wijitphan et al. (2009) & $19,6-60,0$ & Halim et al. (2013) \\
Lumlah anakan & & & $21,0-30,0$ & Lasamadi et al. (2013) \\
\hline $\begin{array}{l}\text { Panjang ruas batang } \\
\text { (cm) }\end{array}$ & $10-12$ & Yassin et al. (2003) & $3,0-4,0$ & Yassin et al. (2003) \\
\hline Panjang daun $(\mathrm{cm})$ & $100-120$ & Heuze et al. (2016) & $\pm 55,0$ & Sirait et al. (2015) \\
\hline Lebar daun $(\mathrm{cm})$ & $1-5$ & Heuze et al. (2016) & $2,0-3,5$ & Sirait et al. (2015) \\
\hline Tinggi $(\mathrm{cm})$ & $400-700$ & CABI (2014) & 79,0 & Halim et al. (2013) \\
& & & 96,3 & Sirait et al. (2015) \\
& & & $108,0-125,0$ & Lasamadi et al. (2013) \\
\hline Bentuk batang & Silinder & Sirait (2017) & Pipih & Sirait (2017) \\
\hline Tipe pertumbuhan & & Tinggi & Rendah
\end{tabular}

yang digunakan berupa komputer, software Microsoft Exel dan Software SPSS versi 26.

Metode penelitian dilakukan dengan melakukan tabulasi data nilai nutrisi, mengukur korelasi nilai nutrisi dengan menggunakan korelasi Pearson two-tailed yang dilanjutkan dengan menyusun persamaan regresi. Uji-t dilakukan sebagai uji lanjut.

Data yang digunakan dalam kajian ini adalah hasil analisis proksimat dan Van Soest dari sampel hijauan rumput gajah tipe tinggi yaitu Pennisetum purpureum. dan rumput gajah tipe pendek kultivar Mott dwarf, yang diperoleh dari Laboratorium Pengujian Pakan, bukubuku dan data yang diperoleh dari jurnal.

Ruang lingkup penelitian yaitu rumput Pennisetum purpureum. Prawiradiputra et al. (2006) menjelaskan rumput ini memiliki ciri-ciri tumbuh membentuk rumpun, perakaran cukup dalam, rhizoma atau rimpang pendek, batangnya tegak, berbuku dan keras bila sudah tua, tingginya bisa mencapai 1,8m - 4,5 m dengan diameter $3 \mathrm{~cm}$, tergantung kultivarnya. Daun keras berbulu yang panjangnya bisa mencapai $90 \mathrm{~cm}$ dan lebar 8-35 cm, bunga berbentuk tandan (seperti es lilin). Tanaman ini dapat tumbuh dengan baik pada dataran rendah dan tinggi dan pada berbagai tanah dengan curah hujan $1.000 \mathrm{~mm}_{\text {tahun }}^{-1}$. Kandungan protein kasar berkisar 7,6\% (tergantung pada kultivar), sedangkan daya hasil mencapai 350-525 ton bobot segar per ha per tahun. Daya hasil setiap panen (interval 45 hari) 8-12 ton bobot segar. Budidaya bisa dengan pols dan stek, panjang stek 20-30 cm (mempunyai dua mata tunas), jarak tanam $1 \mathrm{~m} \times 1 \mathrm{~m}$, pemanenan pertama umur 60-80 hari setelah tanam, pada musim hujan interval panen $30-40$ hari dan musim kemarau 50-60 hari, tinggi pemotongan $15-20 \mathrm{~cm}$ dari permukaan tanah.

Nilai nutrisi yang digunakan untuk analisa yaitu kadar Bahan Kering (BK), abu, Protein Kasar (PK), Lemak Kasar (LK), Serat Kasar (SK), Kalsium (Ca), Phosphor (P), neutral detergent fiber (NDF), acid detergent fiber (ADF) dan Bahan Ekstrak Tanpa Nitrogen (BETN).

\section{RFQ}

Indeks RFQ adalah sebuah peningkatan dari indeks RFV bagi mereka yang membeli dan menjual hijauan, dan RFQ lebih baik dalam merefleksikan performa yang dapat diharapkan dari sapi yang diberi pakan hijauan tersebut. Keuntungan lain dari memprediksi RFQ adalah dapat dipakai untuk membedakan leguminosa dari rumput. Jeranyama \& Garcia (2004) menjelaskan bahwa nilai RFQ dihitung dengan memperkirakan kecernaan bahan kering hijauan, dan berapa banyak sapi bisa makan berdasarkan kapasitas perutnya. Namun, terkadang sapi memiliki kinerja yang berbeda bahkan ketika diberi hijauan RFV identik. Variasi pada kecernaan fraksi NDF dapat menjelaskan perbedaan-perbedaan ini.

Secara alami, kecernaan serat dari rumput dan leguminosa berbeda-beda, seperti halnya ketika tumbuh pada temperatur lingkungan yang berbeda. Alfalfa pada pemotongan pertama, kedua dan ketiga yang dipanen pada tingkat kematangan yang sama akan memiliki nilai RFV yang sama. Namun kecernaan fraksi serat dari setiap pemotongan akan berbeda, karena hal ini dipengaruhi oleh temperatur lingkungan pada saat pertumbuhan dan perkembangan. Oleh karena itu, perbedaan dalam kecernaan serat tidak diperhitungkan dalam perhitungan RFV dan sapi dapat memiliki performa berbeda ketika diberi asupan hijauan dari periode potong yang berbeda (Jeranyama \& Garcia, 2004).

Indeks RFQ dirancang menggunakan kecernaan serat untuk memperkirakan asupan serta total nutrisi yang dapat dicerna (energi) dari hijauan.

RFQ bisa dihitung dengan menggunakan persamaan

$$
\mathrm{RFQ}=(1,2 \cdot \mathrm{RFV})-32,4
$$

Dimana:

$\mathrm{RFV}=(\mathrm{DMI}, \% \mathrm{BB}) \times(\mathrm{DDM}, \% \mathrm{BK}) / 1,29$.

DMI $=$ Dry Matter Indeks $=$ Asupan Bahan Kering $(\%$ $\mathrm{BB})=120 /(\% \mathrm{NDF})$

DDM= Digestible Dry Matter $=$ Bahan Kering Dapat Dicerna $=88,9-(0,779 \times \%$ ADF $)$

$\mathrm{BB}=$ Bobot badan

$\mathrm{BK}$ = Bahan kering 
Nilai NDF yang lebih tinggi pada rumput akan menjadikan indeks RFQ sebagai prediktor kualitas yang lebih baik daripada indeks RFV. Indeks RFQ menekankan kecernaan serat sementara indeks RFV menggunakan asupan bahan kering yang dapat dicerna. Meskipun rumput memiliki fraksi serat yang lebih tinggi (ADF dan NDF), mereka juga memiliki kandungan lignin yang lebih rendah.

RFV terus digunakan secara luas sebagai indeks untuk menilai kualitas, membandingkan varietas hijauan, dan harga hijauan. Namun, perbedaan dalam kecernaan fraksi serat dapat menghasilkan perbedaan dalam kinerja hewan ketika diberi makan hijauan dengan indeks RFV yang sama.

Indeks RFQ telah dikembangkan untuk mengatasi perbedaan ini. Indeks ini mempertimbangkan perbedaan kecernaan fraksi serat dan dapat digunakan untuk memprediksi performa ternak secara lebih akurat dan mencocokkan dengan kebutuhan hewan.

\section{HASIL DAN PEMBAHASAN}

\section{Kadar Nutrien Rumput Gajah Berbeda Tipe Pertumbuhan}

Jumlah data yang digunakan dari berbagai sumber baik hasil analisa sampel dari Balai Pengujian Mutu dan Sertifikasi Produk Hewan (BPMSP) di Bekasi maupun dari jurnal ilmiah yang dikumpulkan bervariasi berkisar antara 6-31 sampel untuk berbagai variabel nutrien. Hasil analisa proksimat dan Van Soest dua tipe rumput

Tabel 2 Tabulasi nutrien Pennisetum purpureum

\begin{tabular}{|c|c|c|c|c|c|c|c|c|c|c|}
\hline \multirow{2}{*}{ Studi } & \multicolumn{9}{|c|}{ Parameter } & \multirow{2}{*}{ Asal Sampel } \\
\hline & BK & $A B U$ & PK & LK & SK & $\mathrm{Ca}$ & $P$ & NDF & ADF & \\
\hline \multirow[t]{6}{*}{ BPMSP, 2015} & 21,82 & 17,40 & 14,53 & 2,21 & 32,65 & 0,47 & 0,31 & 66,85 & 38,92 & Bengkulu \\
\hline & 19,17 & 14,54 & 14,28 & 3,05 & 32,82 & 0,48 & 0,27 & 69,61 & 42,03 & Jawa Barat \\
\hline & 19,91 & 9,94 & 11,44 & 3,10 & 34,66 & 0,24 & - & 73,44 & 46,36 & Lampung \\
\hline & 22,58 & 7,77 & 11,30 & 3,33 & 35,15 & 0,20 & 0,20 & 75,08 & 48,20 & Sumatera Selatan \\
\hline & 19,71 & 18,55 & 8,60 & 2,52 & 32,26 & 0,43 & 0,45 & 68,97 & 41,30 & Bali \\
\hline & 19,84 & 12,20 & 16,84 & 2,98 & 30,41 & 0,28 & 0,26 & 71,65 & 44,33 & Sumatera Barat \\
\hline \multirow[t]{3}{*}{ BPMSP, 2019} & 22,69 & 18,93 & 18,14 & 2,38 & 24,70 & 0,45 & 0,48 & 61,03 & 32,34 & Jawa Barat \\
\hline & 22,95 & 11,98 & 16,64 & 2,84 & 26,94 & 0,45 & 0,22 & 74,41 & 44,84 & Jawa Barat \\
\hline & 21,30 & 13,87 & - & 3,59 & 29,49 & 0,68 & 0,40 & - & - & Jawa Barat \\
\hline \multirow[t]{2}{*}{ UPTD-LPT, 2019} & 19,06 & 13,66 & 9,03 & 1,57 & 33,00 & - & - & 71,85 & 44,56 & Kalimantan Barat \\
\hline & 19,06 & 13,66 & 9,03 & 1,54 & 33,00 & - & - & 71,84 & 44,55 & Kalimantan Barat \\
\hline \multirow[t]{3}{*}{ UPTD-LP, 2019} & 18,45 & - & 15,78 & - & - & - & - & - & - & Jawa Timur \\
\hline & 23,16 & 10,68 & 16,56 & 2,17 & 27,24 & - & - & 74,52 & 47,57 & Jawa Timur \\
\hline & 18,73 & - & 10,66 & - & - & - & - & - & - & Jawa Timur \\
\hline \multirow[t]{4}{*}{ ВРМКР/ВР, 2019} & 19,19 & - & 9,11 & - & - & - & - & - & - & - \\
\hline & 18,71 & - & 8,83 & - & 32,92 & - & - & - & - & - \\
\hline & 22,06 & - & 9,80 & - & - & - & - & - & - & - \\
\hline & 21,86 & 9,65 & 10,19 & 1,88 & 20,89 & 0,21 & - & 81,84 & 55,83 & - \\
\hline Zulbardi M, 2010 & 21,41 & 13,63 & 11,83 & 1,76 & 37,29 & - & - & 68,17 & 40,40 & - \\
\hline Hanifa A, 2008 & 23,95 & - & 14,50 & - & 33,11 & - & - & 70,84 & 43,42 & - \\
\hline \multirow[t]{2}{*}{ Sajimin, et al. 1999} & 20,40 & - & 10,63 & - & - & - & - & - & - & Jawa Barat \\
\hline & 20,40 & - & 8,96 & - & - & - & - & - & - & Jawa Barat \\
\hline AAK, 1979 & 18,98 & 11,73 & 10,19 & 1,64 & 34,15 & - & - & 72,23 & 44,99 & - \\
\hline \multirow[t]{3}{*}{ Bakrie, B et al. 1996} & 18,60 & 11,80 & 8,60 & 3,20 & 31,20 & 0,31 & 0,42 & 67,08 & 39,17 & - \\
\hline & 19,70 & 11,10 & 10,20 & 2,40 & 33,00 & 0,46 & 0,30 & 67,94 & 40,14 & - \\
\hline & 19,80 & 10,59 & 11,51 & - & - & 0,44 & 0,28 & 69,36 & 41,75 & - \\
\hline dairyfeed.ipb.ac.id, 2019 & 22,20 & 12,00 & 8,69 & 2,71 & 32,30 & 0,48 & 0,35 & 65,71 & 37,62 & - \\
\hline \multirow[t]{4}{*}{ Hartadi et al. 2017} & 18,00 & 15,40 & 9,10 & 2,30 & 33,10 & 0,51 & 0,51 & 67,94 & 40,14 & - \\
\hline & 21,00 & 14,10 & 8,30 & 2,40 & 33,50 & 0,53 & 0,29 & 67,94 & 40,14 & - \\
\hline & 20,50 & 10,10 & 3,60 & 1,20 & 32,50 & 0,12 & 0,18 & 67,94 & 40,14 & - \\
\hline & 20,00 & 10,10 & 10,10 & 2,50 & 31,20 & 0,45 & 0,25 & 71,37 & 44,02 & - \\
\hline
\end{tabular}


Tabel 3 Tabulasi nutrien Pennisetum purpureum 'Mott'

\begin{tabular}{|c|c|c|c|c|c|c|c|c|c|c|}
\hline \multirow{2}{*}{ Studi } & \multicolumn{9}{|c|}{ Parameter } & \multirow{2}{*}{ Asal Sampel } \\
\hline & BK & $A B U$ & PK & LK & SK & $\mathrm{Ca}$ & $P$ & NDF & $A D F$ & \\
\hline \multirow[t]{3}{*}{ BPMSP, 2013} & 19,03 & 17,46 & 17,17 & 2,47 & 29,56 & 0,55 & 0,22 & - & - & Jawa Timur \\
\hline & 19,28 & 12,70 & 12,25 & 3,44 & 32,04 & 0,29 & 0,20 & - & - & Jawa Barat \\
\hline & 28,05 & - & 10,21 & 3,28 & 33,97 & 0,42 & 0,36 & - & - & Sulawesi Utara \\
\hline \multirow[t]{6}{*}{ BPMSP, 2015} & 22,64 & 19,65 & 15,23 & 1,69 & 30,83 & 0,45 & 0,59 & 60,59 & - & Jawa Tengah \\
\hline & 22,58 & - & 17,35 & 4,34 & 28,15 & 0,43 & 0,62 & 58,48 & - & Jawa Barat \\
\hline & 27,03 & 12,35 & 10,84 & 2,91 & 29,86 & 0,60 & 0,37 & 67,41 & - & Banyumas \\
\hline & 18,96 & 15,42 & 14,87 & 2,40 & 28,03 & 0,69 & 0,27 & 73,60 & - & Banyumas \\
\hline & 18,62 & - & - & 3,56 & 16,24 & 0,53 & 0,52 & 65,66 & 35,08 & Jawa Barat \\
\hline & 18,41 & 15,77 & 15,32 & 2,26 & 30,75 & 0,27 & 0,28 & 64,65 & - & Sumatera Utara \\
\hline \multirow[t]{3}{*}{ UPTD-LPT, 2019} & 24,84 & 17,01 & 11,73 & 1,50 & 28,63 & - & - & - & - & Kalimantan Barat \\
\hline & 28,30 & 10,08 & 8,89 & 2,45 & 27,10 & - & - & - & - & Kalimantan Barat \\
\hline & 24,84 & 17,01 & 11,73 & 1,50 & 28,63 & - & - & - & - & Kalimantan Barat \\
\hline UPTD-LP, 2019 & 23,68 & 16,28 & 11,94 & 1,98 & 23,37 & - & - & - & - & Jawa Timur \\
\hline BPMKP/BP, 2019 & 22,73 & 12,02 & 15,91 & 1,42 & 32,31 & 0,20 & 0,33 & - & - & - \\
\hline UPTD-PMPP, 2019 & - & 13,81 & 12,51 & 1,39 & 23,44 & - & - & - & - & Sulawesi Selatan \\
\hline Budiman et al. 2012 & - & - & 12,94 & - & 34,94 & - & - & 56,74 & 38,23 & - \\
\hline \multirow[t]{3}{*}{ Lukas et al. 2017} & - & - & 9,97 & - & - & - & - & - & - & Sulawesi Utara \\
\hline & - & - & 9,34 & - & 33,47 & - & - & - & - & Sulawesi Utara \\
\hline & - & - & 9,59 & - & 33,43 & - & - & - & - & Sulawesi Utara \\
\hline Susetyo, 1969 & - & 15,96 & 9,66 & 2,24 & 30,86 & - & - & - & - & - \\
\hline $\begin{array}{l}\text { dairyfeed.ipb.ac.id, } \\
2019\end{array}$ & 20,00 & 8,00 & 11,00 & 2,27 & 30,00 & 0,50 & 0,40 & - & - & - \\
\hline \multirow[t]{4}{*}{ Akbar, 2016} & - & - & 12,04 & - & 26,98 & - & - & - & - & - \\
\hline & - & - & 14,11 & - & 26,06 & - & - & - & - & - \\
\hline & - & - & 15,05 & - & 25,82 & - & - & - & - & - \\
\hline & - & - & 14,00 & - & 26,47 & - & - & - & - & - \\
\hline \multirow[t]{4}{*}{ Juson et al, 2006} & - & 7,93 & 12,59 & - & - & - & - & 68,64 & 40,53 & - \\
\hline & - & 7,44 & 13,08 & - & - & - & - & 67,76 & 38,50 & - \\
\hline & - & 10,39 & 12,34 & - & - & - & - & 66,36 & 38,88 & - \\
\hline & - & 7,79 & 12,54 & - & - & - & - & 68,53 & 40,71 & - \\
\hline
\end{tabular}

gajah dapat dilihat pada Tabel 4. Koefisien keragaman untuk semua parameter kadar gizi pada rumput gajah tipe pendek relatif lebih besar dibandingkan dengan koefisien keragaman nilai nutrisi hijauan rumput gajah tipe tinggi. Hal ini disebabkan oleh jumlah data yang relatif sedikit dibandingkan dengan tipe tinggi. Tingginya keragaman data kadar gizi, juga dipengaruhi oleh asal sampel yang dianalisa dan pengaruh manajemen budidaya tanaman pakan.

Bahan kering hijauan rumput gajah berkisar antara $18 \%$ - 28\% dengan rataan $20 \%$ - 22\%. Selang data bahan kering yang panjang kemungkinan disebabkan oleh musim, umur, kesuburan tanah dan manajemen budidaya tanaman. Tanah yang memiliki tingkat kelembaban tinggi akibat curah hujan akan memberikan kesempatan bagi sistem perakaran untuk menyerap lebih banayak unsur hara tanah, karena terlarut dalam air yang berada pada pori-pori tanah. Oleh karena itu kandungan bahan kering relatif akan lebih tinggi pada musin hujan dibandingkan musim kemarau. Kandar bahan kering juga disebabkan oleh umur panen. Tanaman pada masa awal pertumbuhan hingga pertumbuhan eksponensial memiliki kadar air tinggi dan bahan kering total rendah, kadar serat rendah namun kadar protein dan beberpa mineral tinggi. Kadar karbohidrat dan serat meningkat setelah fase eksponensial dan mendekati masak fisiologisnya (Tillahun et al. 2017). Kadar bahan kering akan didominasi oleh bahan ekstrak tanpa nitrogen dan serat kasar yang bisa mencapai 70\% dari total bahan kering.

Nilai rataan kadar bahan kering hijauan rumput gajah tipe tinggi dan tipe pendek berturut-turut 20,49\% dan 22,60\%. Berdasarkan uji T (Tabel 5) keduanya menunjukkan perbedaan kadar bahan kering yang berbeda nyata $(p<0,05)$. Kadar bahan kering rumput gajah tipe pendek lebih tinggi dibandingkan dengan kadar bahan kering rumput gajah tipe tinggi. Hal ini kemungkinan disebabkan oleh rasio daun-batang pada tipe pendek lebih tinggi berkisar 1,23-1,51 (Santia et al. 2016) dibandingkan dengan tipe tinggi berkisar 0,62- 
Tabel 4 Kadar nutrien dua rumput gajah berbeda tipe pertumbuhan

\begin{tabular}{|c|c|c|c|c|c|c|c|}
\hline \multirow[t]{2}{*}{ Nutrien } & \multirow[b]{2}{*}{ Tipe rumput gajah } & $\mathrm{N}^{1)}$ & Min & Maks & Rataan & \multirow[b]{2}{*}{ SD } & \multirow{2}{*}{$\begin{array}{l}\text { KK } \\
(\%)\end{array}$} \\
\hline & & \multicolumn{4}{|c|}{ \% Bahan kering } & & \\
\hline \multirow[t]{2}{*}{ Bahan Kering } & Tipe tinggi & 31 & 18,00 & 23,95 & 20,49 & 1,61 & 7,86 \\
\hline & Tipe pendek & 15 & 18,41 & 28,30 & 22,60 & 12,16 & 53,81 \\
\hline \multirow[t]{2}{*}{ Abu } & Tipe tinggi & 23 & 7,77 & 18,93 & 12,76 & 2,87 & 22,49 \\
\hline & Tipe pendek & 18 & 7,44 & 19,65 & 13,17 & 15,00 & 113,90 \\
\hline \multirow[t]{2}{*}{ Protein Kasar } & Tipe tinggi & 30 & 3,60 & 18,14 & 11,23 & 3,28 & 29,21 \\
\hline & Tipe pendek & 28 & 8,89 & 17,35 & 12,65 & 5,45 & 43,08 \\
\hline \multirow[t]{2}{*}{ Serat Kasar } & Tipe tinggi & 24 & 20,89 & 37,29 & 31,56 & 3,55 & 11,25 \\
\hline & Tipe pendek & 24 & 16,24 & 34,94 & 28,79 & 16,99 & 59,01 \\
\hline \multirow[t]{2}{*}{ Lemak Kasar } & Tipe tinggi & 22 & 1,20 & 3,59 & 2,42 & 0,64 & 26,45 \\
\hline & Tipe pendek & 17 & 1,39 & 4,34 & 2,42 & 0,72 & 29,75 \\
\hline \multirow[t]{2}{*}{ BETN } & Tipe tinggi & 23 & 33,21 & 57,39 & 41,82 & 5,38 & 12,86 \\
\hline & Tipe pendek & 14 & 32,60 & 51,48 & 40,96 & 29,13 & 71,12 \\
\hline \multirow[t]{2}{*}{ Calsium } & Tipe tinggi & 18 & 0,12 & 0,68 & 0,40 & 0,14 & 35,00 \\
\hline & Tipe pendek & 11 & 0,20 & 0,69 & 0,45 & 0,02 & 4,44 \\
\hline \multirow[t]{2}{*}{ Phosphor } & Tipe tinggi & 16 & 0,18 & 0,51 & 0,32 & 0,10 & 31,25 \\
\hline & Tipe pendek & 11 & 0,20 & 0,62 & 0,38 & 0,02 & 5,26 \\
\hline \multirow[t]{2}{*}{ NDF } & Tipe tinggi & 23 & 61,03 & 81,84 & 70,33 & 4,11 & 5,84 \\
\hline & Tipe pendek & 11 & 56,74 & 73,60 & 65,31 & 24,46 & 37,45 \\
\hline \multirow[t]{2}{*}{ ADF } & Tipe tinggi & 23 & 32,34 & 55,83 & 42,73 & 4,55 & 10,65 \\
\hline & Tipe pendek & 6 & 35,08 & 40,71 & 38,66 & 4,16 & 10,76 \\
\hline \multirow[t]{2}{*}{ RFQ } & Tipe tinggi & 23 & 29,53 & 84,12 & 56,46 & 10,65 & 18,86 \\
\hline & Tipe pendek & 6 & 60,75 & 83,91 & 68,10 & 17,96 & 26,37 \\
\hline
\end{tabular}

1) N: Total sampel; Min: Nilai minimum; Maks: Nilai maksimum; SD: Standar deviasi; KK: Koefisien keragaman

2) BETN: Bahan ekstrak tanpa nitrogen; NDF: Neutral detergent fiber; ADF: Acid detergent fiber; RFQ: Relative Forage Quality

0,70 (Seseray et al. 2013). Daun mengandung air reatif lebih rendah dari pada batang, sehingga kadar bahan kering total tipe pendek dengan porsi daun lebih tinggi memiliki kadar bahan kering relatif lebih tinggi dibandingkan tipe tinggi.

Kadar abu, protein kasar dan lemak kasar hijauan kedua tipe rumput gajah relatif sama pada kedua tipe yaitu berturut-turut 7\%-19\%, 11\%-13\% dan 2,4\%. Demikian pula dengan kadar Ca dan $\mathrm{P}$ berturut-turut antara $0,12 \%-0,68 \%$ dan 0,20\%-0,69\%. Secara morfologi, kedua tipe rumput gajah memiliki sistem perakaran dengan rasio terhadap biomassa atas tanah relatif sama, sehingga kapasitas penyerapan hara tanah relatif terhadap akumulasi bahan kering, sama meskipun berada pada kondisi tanah berbeda akibatnya kadar mineral yang terakumulasi dalam abu menjadi tidak berbeda. Namun kemungkinan kadar mineral bisa saja berbeda pada kondisi tanah yang berbeda (Whitehead, 2000).

Tabel 5 menunjukan kadar serat kasar hijauan rumput gajah tipe tinggi nyata $(\mathrm{p}<0.05)$ lebih tinggi dibandingkan dengan kadar serat kasar pada hijauan rumput gajah tipe pendek $(31,56$ vs 28,79). Demikian pula nilai rataan NDF dan ADF pada rumput gajah tipe tinggi nyata lebih tinggi $(\mathrm{p}<0.05)$ dibandingkan nilai NDF dan ADF pada rumput gajah tipe pendek (berturut turut $70,33 \%$ vs $65,31 \%$ dan $42,73 \%$ vs $38,66 \%$ ) seperti terlihat pada Tabel 4. Secara fisiologis, rumput gajah tipe tinggi memerlukan karbohidrat struktural untuk membentuk dinding sel lebih tinggi dibandingkan rumput gajah tipe pendek untuk menegakkan batang lebih kokoh. Dinding sel berupa selulosa dan

Tabel 5 Uji T kadar nutrien beberapa rumput gajah berbeda tipe

\begin{tabular}{|c|c|c|c|c|c|c|c|c|c|c|c|}
\hline \multirow{2}{*}{ Spesies } & \multicolumn{11}{|c|}{ Parameter } \\
\hline & $\mathrm{BK}^{1)}$ & Abu & PK & LK & SK & $\mathrm{Ca}$ & P & NDF & ADF & RFQ & BETN \\
\hline P purpureum & $20,49^{\mathrm{a} 2)}$ & 12,76 & 11,23 & 2,42 & $31,56^{a}$ & 0,40 & 0,32 & $70,33^{a}$ & $42,73^{a}$ & $56,46^{a}$ & 41,82 \\
\hline $\begin{array}{l}\text { P purpureum } \\
\text { 'Mott' }\end{array}$ & $22,60^{b}$ & 13,17 & 12,65 & 2,42 & $28,79^{b}$ & 0,45 & 0,38 & $65,31^{b}$ & $38,66^{b}$ & $68,10^{b}$ & 40,96 \\
\hline Pvalue & 0,007 & 0,695 & 0,065 & 0,988 & 0,016 & 0,385 & 0,252 & 0,004 & 0,044 & 0,021 & 0,639 \\
\hline
\end{tabular}


Tabel 6 Persamaan regresi kandungan NDF dengan nilai RFQ rumput gajah berbeda tipe

\begin{tabular}{lcc}
\hline $\begin{array}{l}\text { Tipe rumput } \\
\text { gajah }\end{array}$ & Signifikansi & Persamaan Regresi \\
\hline Tipe tinggi & 0,000 & RFQ $=237,527-2,575 N D F$ \\
$\begin{array}{l}\text { Tipe pendek } \\
\text { (mott dwarf) }\end{array}$ & 0,002 & RFQ $=192,366-1,894 N D F$ \\
\hline
\end{tabular}

hemiselulosa berperan penting agar struktur batang lebih massif dan tanaman dapat menopang beban daun yang semakin meningkat bahan keringnya.

Faktor lain yang mempengaruhi kadar serat pada kedua tipe rumput gajah adalah umur panen. Tanaman rumput gajah tipe pendek relatif lebih cepat mencapai umur masak fisiologis, sehingga dipanen lebih cepat yaitu rata-rata umur 30-40 hari dibandingkan dengan tanaman rumput gajah tipe tinggi yang dipanen rata-rata berkisar 40-60 hari. Nilai fraksi serat meningkat seiring dengan peningkatan umur panen (Tillahun et al. 2017). Penebalan dinding sel terjadi lebih intensif saat fase vegetatif hingga tanaman mencapai masak fisiologis, demikian pula karbohidrat larut dalam air (WSC: Water soluble carbohydrate) meningkat hingga puncaknya pada minggu ke 6-7 (Manyawu et al. 2013).

Nilai RFQ mewakili nilai RFV yang menunjukan kualitas hijauan secara biologis. Nilai RFQ dipengaruhi oleh konsumsi bahan kering dan nilai kecernaan bahan kering hijauan pakan. Konsumsi bahan kering hijauan dipengaruhi oleh kadar NDF, dimana semakin tinggi nilai NDF kemampuan ternak untuk mengonsumsi bahan kering hijauan akan menurun. Kecernaan bahan kering dipengaruhi oleh kadar ADF hijauan. Semakin tinggi kadar ADF hijauan maka semakin rendah nilai kecernaan bahan keringnya (Undersander et al., 2010). Tabel 5 menunjukan bahwa nilai RFQ hijauan rumput gajah tipe tinggi memiliki nilai RFQ lebih rendah ( $p<0.05)$ dibandingkan dengan nilai RFQ hijauan rumput gajah tipe pendek $(56,46 \%$ vs $68,10 \%)$. Hal ini berarti bahwa potensi nilai biologis rumput gajah tipe pendek lebih baik dibandingkan tipe tinggi.

Nilai RFQ berkorelasi negatif dengan nilai NDF (Tabel 5). Nilai RFQ hijauan rumput gajah tipe tinggi memiliki nilai gradien 1,3 kali lebih tinggi dibandingkan dengan nilai RFQ hijauan rumput gajah tipe pendek. Hal ini berarti bahwa setiap kenaikan nilai NDF pada hijauan rumput gajah tipe tinggi akan menurunkan lebih cepat nilai RFQ dibandingkan pada hijauan rumput gajah tipe pendek.

Hubungan antara nilai RFQ dan NDF dapat dilihat pada Gambar 1. Kualitas hijauan rumput gajah tipe pendek relatif memiliki nilai NDF lebih rendah dengan selang nilai antara 56-74\%, yang berarti memiliki nilai RFQ berkisar 46,5-92,8, lebih tinggi dibandingkan dengan hijauan rumput gajah tipe tinggi dengan kisaran nilai NDF 61-82\%, yang berarti memiliki nilai RFQ berkisar 37,06 - 76,83. Nilai RFQ tersebut relatif lebih kecil dibandingkan dengan nilai RFQ sorgum berkisar antara 70,8\% - 96,5\% (Wahyono et al.2019).

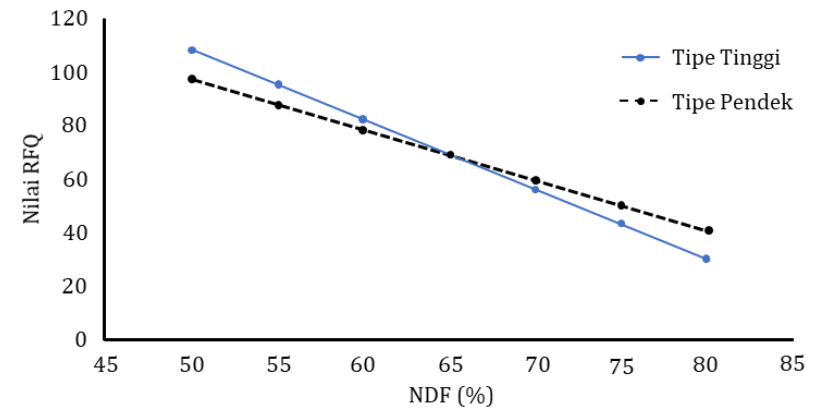

Gambar 1 Hubungan NDF (\%) dengan nilai RFQ hijauan rumput gajah tipe tinggi dan tipe pendek

\section{SIMPULAN}

Nilai kualitas hijauan (RFQ) hijauan rumput gajah tipe pendek lebih tinggi dibandingkan dengan nilai RFQ hijauan rumput gajah tipe tinggi. Dalam hal bahan kering dan fraksi serat, kualitas hijauan rumput gajah tipe pendek kultivar Mott lebih baik dibandingkan kualitas hijauan rumput gajah tipe tinggi.

\section{DAFTAR PUSTAKA}

AAK. 1979. Kawan Beternak. Yogyakarta (ID): Penerbit Kanisius.

Akbar K. 2016. Kandungan Protein Kasar dan Serat Kasar Rumput Gajah Mini (Pennisetum purpureum cv Mott) yang Dipupuk dengan Pupuk Organik Cair [Skripsi]. Makasar (ID): Universitas Hasanuddin

Bakrie B, Hogan J, Liang JB, Tareque AMM \& Upadhyay RC. 1996. Ruminant Nutrition and Production in the Tropics and Subtropics. Canberra (AU): Australian Centre for International Agricultural Research

[BPMKP/BP]. Balai Pengujian Mutu dan Keamanan Pakan/Bahan Pakan. 2019. Kompilasi Hasil Uji Hijauan 2015-2019. Dinas Ketahanan Pangan dan Peternakan, Provinsi Jawa Barat. Unpublished.

[BPMSP] Balai Pengujian Mutu dan Sertifikasi Pakan. 2014. Buku Hasil Uji Bahan Pakan dan Hijauan Pakan Ternak. Bekasi (ID): Direktorat Jenderal Peternakan dan Kesehatan Hewan, Kementerian Pertanian.

[BPMSP] Balai Pengujian Mutu dan Sertifikasi Pakan. 2016. Buku Hasil Uji Bahan dan Hijauan Pakan Ternak. Bekasi (ID): Direktorat Jenderal Peternakan dan Kesehatan Hewan, Kementerian Pertanian.

[BPMSP] Balai Pengujian Mutu dan Sertifikasi Pakan. 2019. Kumpulan Laporan Hasil Pengujian periode 2016-2018. Direktorat Jenderal Peternakan dan Kesehatan Hewan, Kementerian Pertanian. Unpublished

Budiman B, Sutrisno RD, Budhi SPS \& Indrianto A. 2012. Morphological characteristics, productivity and quality of three napier grass (Pennisetum purpureum Schum) cultivars harvested at different age. Journal of the Indonesian Tropical Animal Agriculture. 37:294301.

CABI. 2014. Invasive species Compendium. Datasheets of elephant grass (Pennisetum purpureum). Wallingford (UK): CAB International.

Hanifa A. 2008. Pengaruh Pemberian Ransum dengan Kualitas Berbeda terhadap Profil Darah, Produksi Susu dan PBB Sapi Perah. Sains Peternakan. 6(1):26-33

Halim MRA, Samsuri S \& Bakar IA. 2013. Yield and nutritive quality of nine Napier grass varieties in Malaysia. Malaysian Journal of Animal Science. 16:37-44 
Hancock DW, Saha U, Stewart RL Jr, Bernard JK, Smith RC III \& Johnson JM. 2017. Understanding and Improving Forage Quality. University of Georgia. Georgia: UGA Press

Heuze V, Tran G, Giger-Reverdin S, \& Lebas F. 2016. Elephant grass (Pennisetum purpureum). Feedipedia, a programme by INRA, CIRAD, AFZ and FAO [Internet]. [cited 17 November 2017]. Available from: http://www.feedipedia.org/node/395

Jeranyama P \& Garcia AD. 2004. Understanding Relative Feed Value (RFV) and Relative Forage Quality (RFQ). South Dacota (US). College of Agriculture and Biological Sciences, South Dacota State University.

Juson S, Alimon AR, Halim RA \& Rosenani AB. 2006. The effect of source of fertilizer on the nutritive value of dwarf napier (Pennisetum purpureum CV Mott) silage. Malaysian Journal of Animal Science (2):40-47.

Lasamadi RD, Malalantang SS, Rustandi \& Anis SD. 2013. Pertumbuhan dan perkembangan rumput gajah dwarf (Pennisetum purpureum $\mathrm{cv}$. Mott) yang diberi pupuk organik hasil fermentasi EM4. Zootek Jurnal. 32:158-171.

Lukas RG, Kaligis DA \& Najoan M. 2017. Karakter Morfologi dan Kandungan Nutrient Rumput Gajah Dwarf (Pennisetum purpureum CV. Mott) pada Naungan dan Pemupukan Nitrogen. Jurnal LPPM Bidang Sains dan Teknologi 4(2):33-43.

Manyawu GJ, Chakoma C, Sibanda S, Mutisiand C \& Chakoma IC. 2003. The Effect of Harvesting Interval on Herbage Yield and Nutritive Value of Napier Grass and Hybrid Pennisetums. Asian Australasian Journal of Animal Sciences 16 (7): 996-1002.

Manyawu GJ, Thorne P, Moyo S, Omore A, Lukuyu B, Katjiuongua H, Wright I \& Chakoma I. 2013. Application of the principles of sustainable intensification (SI) on smallholder dairy farming in eastern and southern Africa. Paper presented at the 9th African Dairy Conference and Exhibition, Harare, Zimbabwe, 24-26 September 2013. Available at

http://www.slideshare.net/ILRI/9thafricandairyconf-manyawu [accessed 24 November 2014].

Moore JE \& Undersander DJ. 2002. Relative Forage Quality: An alternative to relative feed value and quality index. Gainesville (US). University of Florida. In: Proc. Florida Ruminant Nutrition Symposium. 16-31.

Prawiradiputra BR, Sajimin, Purwantari ND \& Herdiawan I. 2006. Hijauan Pakan Ternak. Jakarta (ID): Badan Penelitian dan Pengembangan Pertanian. Departemen Pertanian

Rohweder DA, Barnes RF, \& Jorgensen N. 1978. Proposed hay grading standards based on laboratory analyses for evaluating quality. Journal of Animal Science 47:747-759.

Romero JJ, Castillo MS, Burns JC, Moriel P \& Davidson S. 2015. Forage Quality: Concepts and Practices. North Carolina Cooperative Extension. North Carolina University.

Sajimin, Prawiradiputra BR \& Panjaitan M. 1999. Integrasi Tanaman Pakan pada Sistem Usaha Tani di Kecamatan Bayongbong Kabupaten Garut. Jurnal Ilmu Ternak dan Veteriner 4(4):1-7.

Santia, Selvie DA \& Charles LK. 2016. Pengaruh tinggi dan jarak waktu pemotongan rumput gajah dwarf (Pennisetum purpureum cv. mott) terhadap pertumbuhan vegetatif dan produksi bahan kering. "Zootek" Journal 37 (1): 116 - 122

Seseray DY, Santoso B \& Lekitoo MN. 2013. Produksi rumput gajah (Pennisetum purpureum) yang diberi pupuk $\mathrm{N}, \mathrm{P}$ dan $\mathrm{K}$ dengan dosis 0,50 dan $100 \%$ pada defoliasi hari ke-45. Sains Peternakan 11 (1): 49-55
Sirait J. 2017. Rumput Gajah Mini (Pennisetum purpureum cv. Mott) sebagai Hijauan Pakan untuk Ruminansia. Wartazoa 27(4):167176.

Sirait J, Tarigan A \& Simanihuruk K. 2015. Karakteristik morfologi rumput gajah kerdil (Pennisetum purpureum cv. Mott) pada jarak tanam berbeda di dua agroekosistem di Sumatera Utara. Dalam: Noor SM, Handiwirawan E, Martindah E, Widiastuti R, Sianturi RSG, Herawati T, Purba M, Anggraeny YN, Batubara A, penyunting. Bogor (ID): Teknologi Peternakan dan Veteriner.

Sukria HA \& Krisnan R. 2009. Sumber dan Ketersediaan Bahan Baku Pakan di Indonesia. Bogor (ID): Sukria HA dan Krisnan R. 2009. Sumber dan Ketersediaan Bahan Baku Pakan di Indonesia. Bogor (ID): IPB Pres

Susetyo. 1969. Hjauan Makanan Ternak. Direktorat Peternakan Rakyat. Jakarta (ID): Direktorat Jenderal Peternakan.

SNI 01-2891. 1992. Cara Uji Makanan dan Minuman. Badan Standar Nasional. Jakarta (ID): Standar Nasional Indonesia 01-2891-1992.

Sukria HA \& Krisnan R. 2009. Sumber dan Ketersediaan Bahan Baku Pakan di Indonesia. Bogor (ID): IPB Press.

Tilahun G, Asmare B \& Mekuriaw Y. 2017. Effects of harvesting age and spacing on plant characteristics, chemical composition and yield of desho grass (Pennisetum pedicellatum Trin.) Tropical GrasslandsForrajes Tropicales. 5(2):77-84

Undersander D. 2003. The new relative forage quality index-concept and use. World's Forage Superbowl Contest, UWEX. Accessed Sep. 25,

http://www.dfrc.ars.usda.gov/WDExpoPdfs/newRelative FQindex.pdf.

Undersander D, Moore JE \& Schneider N. 2010. Relative Forage Quality. Focus on Forage 12(6):1-3.

[UPTD-LP] Unit Pelaksana Teknis Daerah-Laboratorium Pakan. Kompilasi Hasil Uji Hijauan 2017-2019. Dinas Peternakan Provinsi Jawa Timur. Unpublished.

[UPTD-LPT] Unit Pelaksana Teknis Daerah-Laboratorium Pakan Ternak. 2019. Kompilasi Hasil Pengujian Hijauan 2014-2019. Pontianak (ID): Dinas Peternakan dan Kesehatan Hewan Provinsi Kalimantan Barat. unpublished

[UPTD-PMPP] Unit Pelaksana Teknis Daerah-Pengujian Mutu Produk Peternakan. 2019. Rekapitulasi Uji Hijauan 2017-2019. Dinas Peternakan Provinsi Sulawesi Selatan. Unpublished

Van Soest PJ, Robertson JB \& Lewis BA. 1991. Methode for Dietary Fiber, Neutral Detergent Fiber and Nonstrarch Polysaccharides in Relation to Animal Nutrittion. Journal of Dairy Science. 74:35833597

Wahyono T, Astuti DA, Jayanegara A, Wiryawan IGK \& Irawan S. 2019. Evaluasi Fraksi Serat untuk Mengestimasi Relative Feed Value pada Tanaman Sorgum Galur Mutan. Jurnal Ilmiah Aplikasi Isotop Radiasi 15(2): 93-106

Whitehead DC. 2000. Nutrient elements in grassland. Soilplant-animal relationships. 369 pp. Wallingford (EG): CABI Publishing.

Wijitphan S, Lorwilai P \& Arkaseang C. 2009. Effects of plant spacing on yields and nutritive values of Napier grass (Pennisetum purpureum Schum.) under intensive management of nitrogen fertilizer and irrigation. Pakistan Journal of Nutrition. 8:1240-1243

Yassin M, Malik MA \& Nazir MS. 2003. Effect of different spatial arrangements on forage yield, yield components and quality of mott elephant grass. Jurnal Agronomi.2:52-58

Zulbardi, M. 2000. Daya Konsumsi dan Daya Cerna Kerbau terhadap Rumput Gajah (Pennisetum purpureum varian Hawaii). Bulletin 26:32-40. LPP Bogor. 